\title{
Winter Injury to Fourwing Saltbush
}

\section{GORDON A. VAN EPPS}

Highlight: Winter hardiness of fourwing saltbush (Atriplex canescens) varies with its point of origin. Data indicate that factors other than temperature and origin affect the hardiness of these plants, since variations in winter hardiness occur between individual plants from the same source. The sex of a plant has no effect on hardiness. Generally, seed for reseeding should be obtained from the immediate vicinity of, or from an area colder than, the anticipated planting site.

Fourwing saltbush (Atriplex canescens) occurs widely in the western states. In addition, it is one of the most rapid in vegetative growth and produces an abundance of forage savored by game and livestock. Cold tolerance is only one characteristic

The author is associate professor of range science, Department of Range Science, Utah State University, stationed at Snow Field Station, Snow College, Ephraim, Utah.

The research is a contribution of the Utah Agricultural Experiment Station as Journal Paper number 1874. This report was in cooperation with the Intermountain Forest and Range Experiment Station, U.S. Forest Service.

Manuscript received May 30, 1974. used to measure the performance of this plant in evaluation and selection, but it is one of the more important traits when selecting for future plantings in the colder areas. The unusually severe winter of 1972-73 was ideal for checking the hardiness of plants in Utah. During this period, many ornamental shrubs and trees around homes and buildings, as well as some indigenous shrubs, suffered winter injury.

Fourwing saltbush plants from several sources were planted during 1970 and 1971 at two locations to check their performance as transplants in terms of such characteristics as palatability, vegetative growth, seed production, and winter hardiness. The plantings were at either Snow Field Station in Ephraim, Utah, or Nephi Field Station, south of Nephi, Utah.

The Snow Field Station is in a relatively high and dry mountain valley at an elevation of $5600 \mathrm{ft}$. Some winters are quite mild, with few nights dropping below zero degrees Fahrenheit. Others may be extremely cold, with many below-zero nights. Wind chill is not a problem in this area.

The winter of 1972-73 was characterized by early winter storms 
and long periods of cold temperatures at the Snow Station. Three nights in December, 1972, had temperatures lower than $-20^{\circ} \mathrm{F}$ as well as two nights during January, 1973. The mean minimum temperature during January was a $-1^{\circ} \mathrm{F}$. The 9-month period of September through May brought precipitation of 12.1 inches as compared to a preceding 13-year average of 9.0 inches. Normal annual precipitation is approximately 10.5 inches. Spring was late, followed by hot, dry weather. Snow accumulation varied from 10 to 18 inches.

Nephi Field Station is in a dry farm area on the north slope of Levan Ridge at an elevation of $5240 \mathrm{ft}$. Average yearly precipitation is 12.6 inches. Wind chill is a definite factor at this location.

Precipitation for the 7-month period of October, 1972, through April, 1973, was 13.9 inches as compared to a 70-year average of 7.9 inches for the same months. Temperatures are not recorded at the Station, but at a comparable location a few miles away, the monthly averages during these 7 months varied from a -.6 to $-8.9^{\circ} \mathrm{F}$ departure from normal. The two coldest months were December and January with a $-21^{\circ} \mathrm{F}$ being the coldest temperature recorded. Snow accumulation in 1972-73 was less than at the Snow Field Station, which is unusual.

Plants of fourwing saltbush occur naturally in the Ephraim area. By contrast, none have been observed on Levan Ridge even though introduced plants do exceptionally well and reseed naturally. It is assumed, therefore, that naturally occurring plants on Levan Ridge have been killed out through cultivation or grazing.

\section{Plantings and Results}

One of the 1970-71 plantings on the Snow Field Station consisted of plants from 20 locations. These were obtained either as transplants from a nursery developed from seed planted during July, 1970, or as year-old wildings collected from other locations during 1971. These were planted randomly incorporating six replications. Plants from all were making good to vigorous growth and all had flowered during the 1972 summer months. The pistillate plants produced seed.

Variations in survival among plants from different geographical sources or ecotypes were dramatically evident in 1972-73 (Table 1). Plants originating in areas having relatively mild climates generally suffered the greatest injury. Exceptions, for example, were plants

Table 1. Winter injury (\%) to 20 sources of fourwing saltbush at Snow Field Station.

\begin{tabular}{|c|c|c|c|c|c|}
\hline \multirow[b]{3}{*}{ Plant source ${ }^{1}$} & \multirow{3}{*}{$\begin{array}{c}\text { Mean }^{2} \\
\text { January } \\
\text { minimum } \\
\text { cmperature }\left({ }^{\circ} \mathrm{F}\right)\end{array}$} & \multirow{3}{*}{$\begin{array}{c}\text { Complete } \\
\text { winterkilled }\end{array}$} & \multicolumn{3}{|c|}{ Percent injury to remaining live plants } \\
\hline & & & \multicolumn{2}{|c|}{ Stcm injury } & \multirow{2}{*}{$\begin{array}{l}\text { Top killed } \\
\text { base alive }\end{array}$} \\
\hline & & & Under 50\% & Over $50 \%$ & \\
\hline W. Ephraim, Utah & $15(-25)$ & 0 & 74 & 26 & 0 \\
\hline E. Salina, Utah & $17(-15)$ & 4 & 45 & 50 & 5 \\
\hline Bonanza, Utah & $8(-25)$ & 8 & 68 & 28 & 4 \\
\hline S. Jericho, Utah & $14(-25)$ & 21 & 100 & 0 & 0 \\
\hline Hiawatha, Utah & $14(-18)$ & 26 & 65 & 35 & 0 \\
\hline Canjilon, New Mexico & $3(-35)^{3}$ & 33 & 33 & 67 & 0 \\
\hline Newcastle, Utah & $14(-32)$ & 38 & 100 & 0 & 0 \\
\hline Montrose, Colo. & $13(-27)$ & 39 & 21 & 64 & 15 \\
\hline Keams Canyon, Ariz. & $19(-5)$ & 43 & 33 & 67 & 0 \\
\hline Fry Canyon, Utah & 14 & 48 & 27 & 64 & 9 \\
\hline Milford, Utah & $13(-34)$ & 50 & 50 & 50 & 0 \\
\hline E. Flagstaff, Ariz. & $15(-16)$ & 58 & 50 & 25 & 25 \\
\hline N. Holbrook, Ariz. & $18(-20)$ & 61 & 67 & 33 & 0 \\
\hline Emery, Utah & $11(-20)$ & 68 & 83 & 0 & 17 \\
\hline SE Fredonia, Ariz. & $19(-18)$ & 71 & 20 & 60 & 20 \\
\hline Hanksville, Utah & $9(-35)$ & 71 & 50 & 50 & 0 \\
\hline \multicolumn{6}{|l|}{ Desert Range Exp. } \\
\hline Sta., Utah & $13(-29)$ & 73 & 67 & 33 & 0 \\
\hline E. Flagstaff, Ariz. & $15(-16)$ & 86 & 0 & 100 & 0 \\
\hline \multicolumn{6}{|l|}{ House Rock Valley, } \\
\hline Ariz. & 20 & 94 & 0 & 100 & 0 \\
\hline W. Delta, Utah & $14(-25)$ & 100 & 0 & 0 & 0 \\
\hline
\end{tabular}

${ }^{1}$ Only 4 plants each from Milford and W. Delta were planted and only 8 each from W. Hanksville and Newcastle. All other sources originally consisted of 24 plants. Some sources contained fèwer plants in the fall of 1972 due to disease.

${ }^{2}$ Temperatures are for the plant source. Extreme minimum temperature in parentheses.

${ }^{3}$ Temperatures were obtained from Elvado Dam which are probably lower than at Canjilon.

from the Snake Valley, west of Delta, Utah, Hanksville, and from the Desert Range Experiment Station. These areas may be occasionally colder than Ephraim, but plants from there did not survive well-indicating the probable influence of factors other than temperature. Springfield reported in 1970 that soils influenced the adaptability of particular plant strains. Plants indigenous to the Ephraim, Utah, area suffered few if any complete kills. Although these plants showed some dieback, it was less than for plants from any other source. Apparently, plants indigenous to an area or from similar habitats sustain less loss.

A small nursery of fourwing saltbush was planted from seed June 19,1972 . The original seed sources included 18 sites in Utah, 3 each in Arizona and Idaho, and 1 in Montana. More than ample seed was used to obtain a good stand, as the utricles from some sites were extremely low in seed fill. The resultant plants were to be used as transplant material. All suffered winterkill losses. Seed from near Kanab, Utah, and Lees Ferry, Arizona, which are warm areas, were completely killed. Young seedlings from several central Utah sites varied in injury from stem tip dieback to dead. Plants from seeds collected near Bridger, Montana, showed the least winter injury.

$$
\text { In 1970, 1- to 2-year-old }
$$

transplants, whose original seed source had been near Canjilon, New Mexico, at an approximate 7000-ft elevation, were established at the Nephi Field Station. Plants were spaced with 12 to $80 \mathrm{ft}^{2}$ per plant, depending on plot design, to allow comparison of seed yields. In the fall of 1972, the remaining 1840 live plants consisted of 1025 pistillate, 680 staminate, and 135 bisexual types. It had been postulated that staminate plants might be more winter hardy because of possible greater food storage, while pistillate plants might utilize food reserve to a greater extent in producing abundant fruits. Instead, winter injury did not differ with sex, since nearly $70 \%$ of the plants of each sex were killed. All plants suffered dieback, some much more than others. This planting, as had those already described, showed variations in winter hardiness between individual plants that had the same point of origin. Of the plants suffering top kill, $12 \%$ recovered from excellent basal regrowth. Such regrowth normally involves new buds that start a few inches below the soil surface on the basal stump.

Plants having a decumbent or diffuse growth habit had greater branch survival than the more erect types. This is probably a superficial hardiness brought about by protective snow coverage.

Plants originating near Canjilon, New Mexico, suffered greater winter 


\section{injury when planted on the Nephi} Station than at the Snow Station. This was also true of plants from the west Ephraim source, many of which winterkilled completely when planted at the Nephi Station. These latter plants had made excellent growth at Ephraim during the previous 6 years.

A small planting of transplants collected near Fry Canyon, Utah, were completely killed on the Nephi Station, while only $48 \%$ were killed at the Snow Station. The Nephi Station generally has a 2-week longer growing season and is several degrees warmer than the Snow Station.
Data presented here indicate the need to obtain seed destined for specific areas from strains that are environmentally adapted to that area, since even indigenous strains may suffer injury during unusually severe winters. This ties in with Springfield's (1970) finding on adaptability. Plummer et al. (1968) have indicated that cold-tolerant strains can be planted successfully in warmer climates, but the reverse obviously may be hazardous.

Temperatures are a definite factor in winter injury, but other climatic conditions as well as soil characteristics and availability moisture may also be involved. Winter hardiness varies between individual plants having the same point of origin, as demonstrated by our several plantings of different aged plants from diverse locations.

\section{Literature Cited}

Plummer, A. Perry, D. R. Christensen, and S. B. Monson. 1968. Restoring big-game range in Utah. Utah Division of Fish and Game Publ. 68-3.

Springfield, H. W. 1970. Germination and establishment of Fourwing Saltbush in the Southwest. U.S. Forest Serv. Res. Pap. RM-55. 